\title{
Obituary \\ Richard Wall \\ (2 June 1944-22 June 2011) \\ A personal assessment of his work
}

I first met Richard Wall in late 1982 when I joined the Cambridge Group for the History of Population and Social Structure, which was his intellectual home for much of his working life. Little did I know at the time that this would be the start of a relationship which would last for the near 30 years until his untimely death on 22 June 2011. My arrival at Trumpington Street coincided with an exciting time for the Cambridge Group - with the publication of Wrigley and Schofield's Population history of England the previous year creating what might be termed a halo effect - but also an exciting time for Richard. The page proofs from Cambridge University Press had recently arrived for Family forms in historic Europe which Richard was editing with Peter Laslett and Jean Robin, and these were pored over and discussed at great length. ${ }^{1}$ It was a moment of triumph and celebration for Richard, since, with no disrespect to either of his co-editors, everyone knew that this was very much Richard's book - and quite rightly so. I deliberately start this personal reflection of Richard's intellectual contribution to the discipline to which his research was so central, since in many respects it marked a high point. His extended 'Introduction' essay, together with his chapter on 'The household: demographic and economic change in England, 1650-1750', are still essential reading and mark a starting point for research work on English household and social structure. Indeed, the seminal nature of these two chapters, taken together, somewhat detracts from the other two important chapters on Flanders which Richard contributed to the volume. Family forms also encapsulated a feature that was to become a trademark in much of Richard's writing, namely comparative analysis. In part, this was a wider preoccupation of the Cambridge Group, but Richard would always endeavour to contextualise his research by 
employing comparisons over time and space, so much so that calculating and recalculating figures from household listings in order that they were comparable with the findings of someone else for another place became a common pastime.

Although we did not meet until 1982, like many working in the field, it felt as if I had already known him for years. This was due to his established expertise in the analysis and interpretation of household listings. Graduating in history from King's College London in 1965, Richard went on to complete a Master of Philosophy dissertation at University College London in 1969 entitled 'A history of the development of Walthamstow, 1851-1901', a detailed community study which unfortunately was never translated into published form. Had it been, it would still be viewed as a classic to this day. He joined the newly formed Cambridge Group for the History of Population and Social Structure in 1968 as a 'junior research assistant', specifically to work with Peter Laslett on the analysis of preindustrial listings in preparation for a conference on the subject planned for the following year. This led to the book of the conference, Household and family in past time (HFPT), being published in 1972. With a central theme challenging the then-accepted orthodoxy of the predominance of the extended family as the historic norm for familial organisation across much of the western world, the book, despite its many accepted problems, became a cornerstone of the literature on the subject and arguably served to establish an entirely new sub-discipline of historical enquiry, spawning a multitude of subsequent studies and influencing a whole generation of researchers. Despite the curious attribution of the book as being edited 'with the assistance of Richard Wall', Richard's contribution to the volume cannot and should not be underestimated. In addition to his own chapter on 'Mean household size in England from printed sources', his research underpinned the contributions of his co-editor.

Following HFPT, as it came to be known in Cambridge Group circles, Richard then turned attention to regional variations in household structure within Great Britain, an unexplored theme within the book. His two chapters, 'Regional and temporal variations in English household structure from 1650' and 'Regional and temporal variations in the structure of the British household since 1851', broke new ground and demonstrated that whilst regional variation in family formation appeared to be weak within Britain, important contrasts, especially in relation to non-kin residential arrangements - servants and lodgers - could be witnessed. At the same time as researching regional variations in household structure, Richard also edited several volumes in the Pioneers of demography series published by Gregg International. Unfortunately, these volumes are quite difficult to come by these days and are therefore regrettably too often 
overlooked, yet his thoughtful and informative introductions to the volumes show that he was clearly able to discuss demographic issues in the wider context of key social and economic drivers such as health, housing, poverty and unemployment.

During this period, Richard also started the task of linking the existing and well-known family reconstitution for the Devonshire village of Colyton, originally constructed by Tony Wrigley, with other existing parish records. These included not only the nineteenth-century census enumerators' returns, which added a household dimension to the otherwise demographic record, but also the detailed feoffees' records that gave information of charitable support within the parish since the midsixteenth century (see 'Reconstitution and census', 1976). I mention this work specifically - laboriously undertaken by hand over many years, later with the tireless help of Jean Robin - as it became fundamental to much of Richard's subsequent thinking and writing. I have not counted the number of chapters and articles in which Richard drew in one way or another upon the rich Colyton material, but I would not be surprised if it featured in one form or another in at least a half of his published output, especially up until his move from Cambridge to the University of Essex in 2001.

Richard was interested in more than comparative household structure. Over time, he became increasingly interested in familial organisation, both within and without households, as well as, importantly, between households. Following the classic work of Rowntree, Bowley, Hogg and others - whose publications he collected and which I borrowed from his shelves on a regular basis - he was interested in crisis points within the family lifecycle. In particular, he was interested in how such crises might be mitigated against through the actions of the members of the family and the household of which it was a part, together with interventions from outside the household via extended family members and kin, as well as external mechanisms such as charity and poor relief.

In part, this fascination with what might be termed hardship possibly stems from his childhood experiences. Born on 2 June 1944 and brought up in the period of post-war austerity in Abergavenny, Monmouthshire (often referred to as the gateway to Wales), his father died whilst he was still quite young. Thus, he had direct experience of the widows, women alone and single-parent families that so often became the focus of his investigations. Perhaps his first step in this direction was through the investigation of the residential position of the elderly, now a big topic and a well-ploughed field. This was not so much the case when Richard first turned his attentions to the subject, with two chapters 'The living arrangements of the elderly' and 'The residence patterns of the elderly in 
Europe' published in 1989, and his earlier chapter in The upheaval of war, co-edited with Jay Winter a year earlier also exploring the subject. His work on the elderly led him into researching more contemporary populations, working with others to analyse data sources for the latetwentieth century, such as the UK Longitudinal Study alongside historical materials, something which is still, regrettably, fairly novel. Alongside the elderly, innovative research on leaving the parental home (such as the important article published in this journal, 'Leaving home and the process of household formation in pre-industrial England', 1987) and protoindustrialisation were undertaken on this period. On the latter, I still feel that his concept of an adaptive family economy has much to offer to our understanding of household structure and familial organisation in the present as much as the past ('Work, welfare and the family', 1986).

His move from Cambridge to the Department of History at the University of Essex in 2001, following spells of short-term teaching there, in part also coincided with his research placing greater emphasis on poverty, poor relief, widowhood and access to property. This refocusing was also, without doubt, in part a consequence of his new partnership with Beatrice Moring who was researching into similar areas, and led to a highly successful and productive period of publication (for example, 'The contribution of the Poor Law in England, 2006; 'Widows and unmarried women as taxpayers', 2007; 'Broken families: economic resources of women', 2007; 'Bequests to widows and their property', 2010). It is perhaps fitting that his final book, The Welfare of widows in Northern Europe was written with Beatrice, and is scheduled to be published later this year. Another work planned for posthumous publication is a collection of essays on the life and work of Le Play. The work of Pierre Guillaume Frédéric Le Play and his followers published in Les Ouvriers européens (1855), which produced 36 monographs capturing detailed information on family budgets, was something of a long-term obsession of Richard's, and something which he returned to, again and again, reworking the numbers for comparative purposes. It was Richard in his element and it is highly appropriate that a book of his reanalysis and interpretation of Le Play will be published at a future date.

In addition to his own writing, for almost the entirety of his working academic life Richard was also the editor of two journals: Local Population Studies (LPS) and, of course, this journal, Continuity and Change. He joined the Editorial Board of LPS in 1971 as Secretary to the board (in those days $L P S$ did not have a named editor, but this was the job that Richard undertook). He held this post until 1986 when he stood down to enable him to devote more time to working on Continuity and Change, of which he was founding editor together with Lloyd Bonfield, a 
post he held for 25 years until the time of his death. To apply the simple word 'editor' again undermines his contribution to both publications. $\mathrm{He}$ devoted himself and worked tirelessly to the benefit of the journals under his charge. In the case of both, I have known him to conduct lengthy and detailed exchanges with prospective authors, helping them to bring their original submission to point at which it was deemed publishable. Some might take years to 'knock into shape', but, true to form, Richard would prefer to put in the effort required to see an article through rather than to coldly reject a submission. It is undoubtedly the case that many publications would never have seen the light of day without Richard's support and input. The role of editor suited Richard for it gave him a vehicle to display his many great qualities: scholarship undoubtedly, but also his grace and generosity in the help, support and kindness which he gave and showed to others.

KEVIN SCHÜRER

Kevin Schürer was a colleague of Richard Wall's, both in the Cambridge Group and at the University of Essex, and is now Pro-Vice Chancellor (Research and Enterprise) and Professor of English Local History, University of Leicester.

\section{ENDNOTE}

1 For reasons of brevity, full references to the publications mentioned in this assessment will not be made. A complete listing of the publications of Richard Wall was provided in a previous issue of this journal and readers are directed there for further details; see Lloyd Bonfield, 'Richard Wall - a personal tribute', Continuity and Change 26, 2 (2011), 139-47, here 141-7. 